\title{
ISLAM DAN HAK ASASI MANUSIA DALAM PENDIDIKAN
}

\author{
Ahmad Darmadji \\ Fakultas Ilmu Agama Islam (FIAI) Universitas Islam Indonesia (UII) Yogyakarta \\ Email: ahmaddarmadji@yahoo.com
}

\section{Abstract}

This paper analyzes the issue of. buman rights in the Islamic perspective and its relationship to education in Indonesia. That vision of Islam as mergy for universe can be seen from the universal values and the concern for the basic needs of every person who later becomes a part of buman rights. Basic needs are basically in line with the thinking of international buman rights which are declared as universal declaration of buman rights. Fulfillment and protection of basic needs which are needed to ensure that all people get their rights property.

مستخثلهر

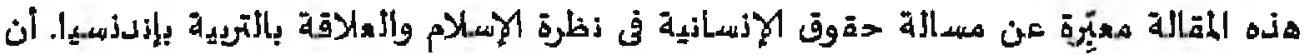

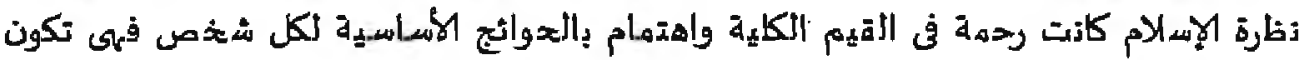

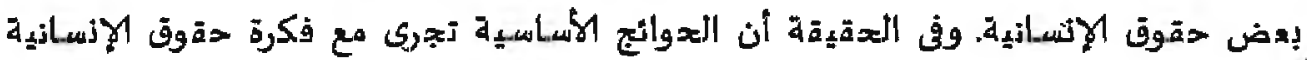

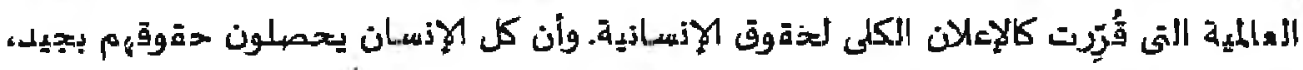
القضضاء وخماية التوائج الكساسية.

Keywords: Pendidikan, Islam, Hak Asasi Manusia, Nilai Kebebasan

\section{A. Pendahuluan}

United Nation Education, Scientific and Cultural Ónganization(UNESCO) atau badan Perserikatan Bangsa-Bangsa (PBB) bidang pendidikan, sains dan budaya untuk wilayah Asia Pasifik telah melakukan penelitian di negara-negara Asia 
termasuk Indonesia. Salah satu kesimpulannya antara lain bahwa sistem pendidikan di Indonesia kurang mengakomodasi hak asasi manusia (HAM) peserta didik. Karenanya Departemen Pendidikan Nasional (Depdiknas) dengan rekomẹndasi dari UNESCO mencanangkan sistem pendidikan berbasis HAM untuk semua jenjang pendidikan. Masalah hak asasi manusia akan di implementasikan dalam kurikulum pendidikan. Untuk pendidikan dasar dan menengah, masalah HAM akan di integrasikan dalam mata pelajaran agama.

Keperluan penjelasan tentang arti, fungsi, peran, posisi dan isi pendidikan berbasis HAM relevan dengan perkembangan nasional dewasa ini yang sedang berusaha membangun kepercayaan publik tentang penegakkan HAM di Indonesia. Satu di antaranya melalui kebijakan otonomi pendidikan yang sejalan seiring dengan kebijakan otonomi daerah. Dengan demikian kebijakan otonomi pendidikan pada dasarnya merupakan pencerahan dan pemberdayaan pendidikan agar lebih bermakna. Lembaga pendidikan dituntut untuk mampu mengembangkan kepribadian peserta didik seutuhnya secara optimal, selain berusaha untuk meningkatkan kemampuan akademis.

Pendidikan berbasis HAM saat ini menjadi satu kebutuhan. Sebab, pendidikan merupakan sarana paling efektif untuk menegakkan prinsip-prinsip HAM. Kendati kenyataan lain menunjukkan bahwa pendidikan di Indonesia masih kurang mengakomodasi HAM peserta didik. Hal ini merupakan kritik untuk terus meningkatkan peran dunia pendidikan dalam melindungi HAM. Dunia pendidikan masih menampilkan sistem yang kurang manusiawi atau ada kecenderungan dehumanisasi. Kebijakan dalam pelaksanaan Ujian Nasional (UN) misalnya yang disinyalir melanggar HAM seharusnya tidak perlu terjadi. Pendidikan seharusnya memperlakukan siswa didik sebagai manusia yang utuh, sehingga tujuan utama pendidikan untuk menciptakan manusia yang bukan hanya unggul dalam bidang kognitif tetapi juga harus bisa menjadikan siswa didik unggul secara afektif maupun psikomotorik.

Pendidikan diyakini sebagai instrumen yang sangat strategis dalam penyebaran nilai-nilai HAM ini. Karenanya, dunia pendidikan diharapkan dapat membantu proses pembelajaran HAM di tingkat pelajar yang nantinya akan memperkuat pemahaman para peserta didik untuk lebih memahami pentingnya 
nilai-nilai HAM.Di sisi lain tidak bisa dipungkiri bahwa tidak jarang nilai-nilai HAM dihadapkan dengan nilai lain seperti nilai universal Islam, kendati pada saat yang bersamaan kadang juga keduanya - nilai HAM dan nilai Islamdisandingkan. Upaya menyandingkan keduanya tentu bukan hal yang berlebihan namun menjadi kebutuhan, karena pada konteks Indonesia, masyarakat muslim merupakan masyarakat mayoritas, termasuk di dalamnya peserta didik sebagai bagian dari masyarakat yang ada yang harus memahami, menarapkan dan menjunjung tinggi nilai-nilai HAM dan sekaligus nilai-nilai Islam sebagai agama yang dianut mayoritas peserta didik.

Dalam konteks Indonesia, pelaksanaan HAM mendapat tantangan kultural berkaitan dengan universalitas, nilai dan prinsip HAM saat ini. Perdebatanperdebatan sosial dan budaya mengenai esensi dan eksistensi HAM pun terus tak terelakan. Kalangan agamawan fundamentalis dan entitas adat menolak penyeragaman HAM karena sebagian prinsip dan nilai HAM bertentanngan nilai-nilai yang diyakininya.Atas dasar hal-hal sebagaimana disebutkan di ataslah, tulisan ini mencoba mendialogkan nilai-nilai kemanusiaan universal Islam dan Hak Asasi Manusia (HAM) dalam koridor buququl-insaniyyab (hak-hak kemanusiaan) khususnya dalam konteks pendidikan.

\section{B. Sekilas tentang HAM dan Perkembangannya}

Berbicara tentang Hak Asasi Manusia (HAM), tidak lepas dari pemahaman "hak" itu sendiri. Hak seringkali dipahami merupakan unsur normatif yang melekat pada diri setiap manusia yang dalam penerapannya berada pada ruang lingkup hak persamaan dan hak kebebasan yang terkait dengan interaksinya antara individu atau dengan instansi. Hak juga merupakan sesuatu yang secara asasi harus diperoleh oleh setiap manusia tanpa terkecuali.

Hak Asasi Manusia (HAM) adalah seperangkat hak yang melekat pada hakekat dan keberadaan manusia sebagai makhluk Tuhan Yang Maha Esa dan merupakan anugerah-Nya yang wajib dihormati, dijunjung tinggi, dan dilindungi oleh negara, hukum, pemerintah dan setiap orang, demi kehormatan serta perlindungan harkat dan martabat manusia. ${ }^{1}$ Karenanya HAM tidak perlu

'Undang-Undang Nomor 39 Tahun 1999 tentang Hak Asasi Manusia (HAM) pasal 1. 
diberikan, dibeli ataupun diwarisi, karena HAM adalah bagian dari manusia secara otomatis. HAM berlaku untuk semua orang tanpa memandang jenis kelamin, ras, agama, etnis, pandangan politik atau asal-usul sosial dan bangsa. HAM tidak bisa dilanggar, sehingga tidak seorangpun mempunyai hak untuk membatasi atau melanggat hak orang lain. Orang tetap mempunyai HAM walaupun sebuah negara membuat hukum yang tidak melindungi atau melanggar HAM. $^{2}$ Konstitusi menatapkan bahwa pelanggaran HAM adalah setiap perbuatan seseotang atau kelompok orang termasuk aparat negara baik disengaja ataupun tidak disengaja atau kelalaian yang secara hukum mengurangi, menghalangi, membatasi dan atau mencabut HAM seseorang atau kelompok orang yang dijamin oleh Undang-Undang ini, dan tidak didapatkan atau dikhawatirkan tidak akan memperoleh penyelesaian hukum yang berlaku. ${ }^{3}$

Tanggung jawab pemajuan (promotion), penghormatan dan perlindungan (protection) HAM tidak saja dibebankan kepada negara, melainkan juga kepada individu warga negara. Artinya negara dan individu sama-sama memiliki tanggung jawab terhadap pemajuan, penghormatan dan perlindungan HAM. Karena itu, pelanggaran HAM sebenarnya tidak saja dilakukan oleh negara kepada rakyatnya, melainkan juga oleh rakyat kepada rakyat yang disebut dengan pelanggaran HAM secara horizontal.

Pada awal perkembangannya, sebagaimana dimaklumi bahwa pengakuan HAM di Etopa dimulai dengan lahirnya Magna Charta yang antara lain memuat pandangan bahwa raja yang tadinya memiliki kekuasaan absolute (raja yang menciptakan hukum, tetapi ia sendiri tidak terikat dengan hukum yang dibuatmya), menjadi dibatasi kekuasaannya dan mulai dapat diminta pertanggungjawabannya dimuka hukum. ${ }^{4}$ Sementara di Amerika, ditandai dengan munculnya The American Declaration of Independence yang lahir dari paham Rousseau dan Montesquieu. Mulailah dipertegas bahwa manusia adalah

\footnotetext{
2Mansyut Fakih dkk, Menegakkan Keadilan dan Kemanusiaan, (Yogyakarta: Insist Press, 2003), hal, 108.

${ }^{3}$ Undang-Undang RI Nomot 26 tahun 2000 tentang Pengadilan HAM.

4A. Mansyur Effendi, Perkembangan Dimensi Hak Asasi Manasia (HAM) Proses Dinamika Penjusunan Hukum Hak Asasi Manusia (HAKHAM)(Bogor: Ghalia Indonesia, 1994), hal. 17-31.
} 
merdeka sejak di dalam perut ibunya, sehingga tidaklah logis bila sesudah lahir ia harus dibelenggu.

Selanjutnya, pada tahun 1789 lahirlah The French Declaration (Deklarasi Perancis) dimana ketentuan tentang hak lebih dirinci lagi sebagaimana dimuat dalam The Rule of Law yang antara lain berbunyi "tidak boleh ada penangkapan tanpa alasan yang sah". Dalam kaitan itu berlaku prinsip presumption of innocent, artinya orang-orang yang ditangkap, kemudian ditahan dan dituduh, berhak dinyatakan tidak bersalah, sampai ada keputusan pengadilan yang betkekuatan hukum tetap yang menyatakan ia bersalah.

\section{Ratifikasi HAM Internasional dan Sistem Ketatanegaraan Indonesia}

Diakui bahwa hingga saat ini implementasi penegakan HAM masih menghadapi kendala struktural dan kultural. Kendala struktural bisa diidentifikasi dari fenomena belum sepenuhnya instrumen kebijakan HAM bisa dijalankan secara maksimal oleh aparatur kelembagaan dan penegak hukum dan HAM. Sementara dari sisi kultural, terjadi pertentangaan-pertentangan nilai di berbagai negara dan masyarakat mengenai konsepsi HAM yang berlaku saat ini.Ada sejumlah negara, khususnya yang berada di kawasan Asia, menganggap HAM bukan sesuatu yang universal: Menurut mereka yang berpaham antiuniversalitas HAM itu, pengakuan universalitas HAM berarti mengingkari adanya relativisme kultural yang ada di bumi ini.

Sebagian pihak belum sepenuhnya mengakui HAM sebagai satu instrumen kebijakan negara' yang harus dijunjung tinggi dan dilaksanakan oleh warga/masyarakat di suatu negara. Berdasarkan alasan historis berbagai pihak menillai bahwa konsepsi/nilai-nilai HAM merupakan konsepsi negara-negara Batat yang dipaksakan kepada negara-negara berkembang di Timur untuk dijalankan.Jika diamati seksama, persoalan-persoalan struktural dan kultural yang muncul disebabkan berbagai asumsi-asumsi persoalan sebagai berikut:

1. Belum adanya konsepsi dan pendidikan HAM yang lebih adaptif yang disesuaikan dengan realitas sosial, budaya dan adat masyarakat Indonsia.

2. Penanganan pelanggaran HAM masih dilakukan pada pendekatanpendekatan kasus hukum atau lebih menitikberatkan pada sisi sipil dan 
politiknya. Sementara, pelanggaran-pelanggaran terhadap hak-hak sosial, ekonomi dan budaya belum menjadi perhatian negara.

3. Kapasitas aparatur negara (kelembagaan) dinilai masih lemah dalam menjalankan instrumen kebijakan HAM baik di tingkat nasional maupun daerah yang sudah terbentuk.

4. Lemahnya praktek pendidikan dan kampanye HAM untuk mendorong kesadaran berbagai pihak (negara-rakyat) untuk mengetahui, memahami, menerapkan konsepsi HAM yang lebih adapatif dan lokalistik.

Upaya Indonesia, dilihat dari sisi sistem ketatanegaraan, untuk terlibat aktif dalam memajukan dan menegakkan HAM sudah dilakukan setidaknya mejalui dua instrumen kebijakan yaitu kebijakan tata hukum (konstitusional) daninstrumen kelembagaan (institusional) sebagai alat untuk menjalankan instrumen yang ada. Dari sudut konstitusional, negara sudah mengakui danmeratifikasi berbagai peraturan internasional tentang HAM ke dalam sistem hukum Indonesa. Aturan-aturan yang sudah dirumuskan termuat dalam beberapa aturan, diantaranya sebagai berikut:

1. Undang-undang Dasar Negara Republik Indonesia Tahun 1945 dan pexubahannya Bab XA tentang Hak Asasi Manusia. ${ }^{5}$

2. Ketetapan Majelis Permusyawaratan Rakyat Republik Indonesia (Tap MPR RD) Nomor XVII/MPR/1998 tentang Hak Asasi Manusia..

3. Undang-undang Republik Indonesia Nomor 39 Tahun 1999 tentang Hak Asasi Manusia.

4. Keputusan Presiden Republik Indonesia Nomor 40 tahun 2004 tentang Rencana Aksi Nasional Hak Asasi Manusia Indonesia tahun 2004-2009.?

Sementara itu secara institusional, Negara Indonesia memiliki instrumen kelembagaan untuk menjalankan sistem/aturan yang ada.Instrumen yang dimaksud antara lain adalah:

5Undang-undang Dasar Negara Republik Indonesia Tahun 1945 hasil Amandemen ke-3.

6Tap MPR RD) Nomor XVII/MPR/1998 tentang Hak Asasi Manusia.

${ }^{\top}$ Keppres Nomor 40 tahun 2004 tentang Rencana Aksi Nasional Hak Asasi Manusia Indonesia tahun 2004-2009. 
1. Komite Nasional Hak Asasi Manusia (Komnas HAM) yang dibentuk sesuai dengan Keputusan Presiden Nomor 50 Tahun 1993 yang kemudian dikukuhkan dengan Undang-undang Nomor 39 Tahun 1999.

2. Pembentukan Kantor Menteri Negara Hak Asasi Manusia pada tahun - 1999 yang kemudian bergabung dengan Departemen Hukum dan

- Perundang-undangan yang kemudian berubah menjadi Departemen Kehakiman dan Hak Asasi Manusia.

3. Komisi Perlindungan Anak Indonesia (KPAI) sesuai dengan Keputusan Presiden Republik Indonesia Nomor 77 Tahun 2003. Lembaga ini bersifat independen yang dibentuk berdasarkan Undang-undang Nomor 23 Tahun 2002 tentang Perlindungan Anak dalam rangka meningkatkan efektifitas penyelenggaraan perlindungan anak. ${ }^{9}$

4. Komisi Perlindungan Anak Indonesia Daerah (KPAID) sesuai Surat Keputusan Komisi Perlindungan Anak Indonesia Nomor 02/KPAI/IX/2004 tentang Pedoman Pembentukan Komisi Perlindungan Anak Indonesia Daerah (KPAID). Lembaga ini bersifat independen yang dibentuk untuk kepentingan anak di daerah provinsi dan/atau kabupaten/kota.Pembentukan KPAD bukan merupakan kewajiban atau keharusan tetapi merupakan kebutuhan daerah masingmasing. ${ }^{10}$

5. Panitia Pelaksana Kegiatan Rencana Aksi Nasional Hak Asasi Manusia (RANHAM). Untuk mèlaksanakan RANHAM Indonesia telah dibentuk suatu Panitia Nasional yang berkedudukan di bawah dan bertanggung jawab langsung kepada Presiden.

Kendati upaya baik secara konstitusional maupun institusional sudah dibentuk, namun kenyataan di lapangan, praktek pelaksanaan penegakan atas hak-hak dasar manusia (HAM) di Indonesia belum sepenuhnya membuahkan perubahan progresif dan baik bagi penghargaan dan penghormatan, perlin-

${ }^{8}$ Keputusan Presiden Nomor 50 Tahun 1993 tentang Komnas HAM

9Undang-undang Nomor 23 Tahun 2002 tentang Petlindungan Anak dan Keppres RI Nomor 77 Tahun 2003 tentang Komisi Petlindungan Anak Indonesia (KPAD).

${ }^{10}$ Surat Keputusan Komisi Perlindungan Anak Indonesia Nomor 02/KPAI/IX/2004 tentang Pedoman Pembentukan Komisi Perlindungan Anak Indonesia Daerah (KPAID) 
dungan terhadap otoritas kemanusiaan dan hak elonomi, sosial dan budaya. Banyak ditemukan fenomena persoalan yang menunjukan implementasi HAM belum berjalan secara maksimal.

\section{Islam dan Hak Asasi Manusia (HAM)}

Pembicaraan mengenai Islam dan HAM menjadi topik yang terus bergulir dalam wacana kontemporer. Mengingat sejarah HAM modern dibangun dalam peradaban Barat, sejumlah pemikir muslim menganggap Islam lebih superior dengan ajaran ilahiyahnya, sehingga tidak memandang perlunya HAM maupun penerapannya. Sebaliknya pada sisi lain, sekelompok pemikir justru melihat nilai universal Islam sebagai celah bagi pentingnya menerapkan HAM dalam bagian integral kehidupan umat Islam. Dua kutub pandangan ini masih ditambah lagi oleh pandangan pertengahan yang melikat HAM dan penerapannya sebagai bagian dari dinamika kekuasaan di setiap negara, termasuk negara Islam. ${ }^{1 t}$

Meskipun dalam Islam hak-hak asasi manusia tidak secara khusus memiliki piagam sebagai penanda pengakuannya secara historis, akan tetapi sejumlah pemikir memiliki pandangan bahwa Islam dan Barat memiliki sejumlah persamaan mendasar dalam kaitannya dengan semangat persamaan (egaliter), kebebasan (freedom), dan keadilan (justice). Ketiganya merupakan fondasi utama bagi pengarusutamaan HAM secara internasional sehingga dengan demikian, secara prinsip Islam juga mengakui dan bahkan menganjurkan perlindungan dan pemenuban HAM. ${ }^{12}$ Tentu saja pemaknaan dari ketiganya sẹcara umum juga memiliki perbedaan antara konsep yang diakui Islam maupun yang dipraktekkan Barat. Islam misalnya lebih mengedepankan pendekatan teosentris dalam

1'Lihat misalnya Sus Eko Emada, "Issues of Compatibility of Human Rights and Islam: the Experience of Egypt and Indonesia", dalam Joumal of Indonesian Islam (Surabaya: Lembaga Studi Agama dan Sosial, Program Pascasarjana Institut Agama Islam Negeri Sunan Ampel, 2007), Vol. 1, No. 1, Hal. 100-134 dan Mohamad Hudaeri, "Islam dan Hak Asasi Manusia: Respon Intelektual Muslim", dalam Alqalam: Jumal Imiah Bidang Keagamaan dan Keriasyarakatan (Banten: PPPM Institut Agama Islam Negeri Sulean Maulana Hasanuddin, 2007), Vol. 24, No. 3 , Hal 364386.

${ }^{12}$ Qomarul Huda, "Hak-hak Asasi Manusia: Mencari Akar Persamaan antara Islam dengan Bame", dalam Abkam: Jamal Huksm Islam, (Tulungagung: Jurusan Syariah Sekolah 'Tinggi Agama Islam Negeri Tulungagung, 2009), Vol 11, No. 1, Hal. 36-55 
memandang masalah HAM, sehingga memiliki nilai keagamaan. Sedangkan Barat lebih memilih melihat HAM dengan pendekatan antroposentris sebagai konsekuensi sejarah, sehingga muatan agama seolah hilang di dalamnya. ${ }^{13}$

Dalam konteks Islam, dua sumber hukum utama, Alqur'an dan Sunnah,telah memusatkan perhatian pada hak-hak yang bahkan-kadang diabaikan pada deklarasi dan piagam peradaban lain. Nash-nash ayat Al-Qur'an yang terkait dengan hal tersebut sangat banyak, dan tidak sulit untuk diungkapkan.Nabi SAW telah menegaskan hak-hak ini dalam suatu pertémuan besar internasional, yaitu pada haji wada'(haji terakhir sebelum Nabi SAW wafat). Pada sebuah Hadits dari Abu Umamah bin Tsa'labah, Nabi SAW pernah bersabda: "Barangsiapa merampas hak seorang muslim, maka dia telah berhak masuk neraka dan haram masuk surga." Seorang lelaki bertanya: "Walaupun itu sesuatu yang kecil, wahay Rasulullah?" Beliau menjawab: "Walaupun hanya sebatang kayu arak."14

Pada haji wada` Rasulullah juga menegaskan secara gamblang tentang hakhak asasi manusia, baik pada lingkup muslim dan non-muslim, pemimpin dan rakyat, laki-laki dan wanita. Pada khutbah itu Nabi SAW juga menolak teori Yahudi mengenai nilai dasar keturunan. Manusia di mata Islam semua sama, .walau berbeda keturunan, kekayaan, jabatan atau jenis kelamin. Ketakwaan-lah yang membedakan mereka. Rakyat dan penguasa juga memiliki persamaan dalam Islam. Yang demikian ini hingga sekarang belum dicapai oleh sistem demokrasi modem. Nabi saw sebagai kepala negara juga adalah manusia biasa, berlaku terhadapnya apa yang berlaku bagi rakyat. Maka Allah memerintahkan Nabi SAW untuk menyatakan: "Katakanlah bahwa aku hanyalah manusia biasa, hanya saja aku diberi wahyu, bahwa Tuhanmu adalah Tuhan yang Esa."

Apa yang disebut dengan hak asasi manusia dalam deklarasi "HAM internasional, tidak lain adalah keharusan atau hak dasar (dbaruriy) yang mana

${ }^{13}$ Taufiqul Hulam, "Hukum Islam Menjunjung Tinggi Hak Asasi Manusia (HAM): Telaah Kritis atas Kontroversinya dengan Barat dan Aplikasinya dalam Dimensi Etika di Indonesia, dalam Respublika: Jumal Hukum (Riau: Fakultas Hukum Universitas Lancang Kuning, 2003), Vol. 3, No. 1, Hal, 1-18.

${ }^{14} \mathrm{HR}$ Muslim.

15QS. Al-Kahfi (18): 110. 
masyarakat tidak dapat hidup tanpa dengannya. Para Ulama muslim mendefinisikan hak dasar tersebut sebagai Ad-Dharurat Al-Khams (lima hak dasar), dimana kelimanya merupakan tujuan akhir syari'ah Islam. Kelima hak dasar dimaksud adalah menjaga akal, agama, jiwa, kehormatan dan harta benda manusia. $^{16}$

Sebagian umat Islam menyadari bahwa sesungguhnya Islam lebih dahulu menetapkan dan mengakuai hak-hak dasar manusia sejak 1400 abad lalu jauh sebelum dekalarasi HAM pada beberapa Negara baik di Eropa maupun Amerika. Sebagaimana jauh sebelum masyarakat dunia menghapus perbudakan, Islam telah lebih dahulu melakukannya. Islam memberikan sejumlah hak kepada manusia, baik bak dalam politik, ekonomi, sosial pendidikan, berkeluarga dan lain-lain. Hak hidup dan keselamatan diri, hak memperoleh perlindungan diri, kehormatan dan hak memiliki harta merupakan hak-hak terpokok dalam Islam. Betapa banyak ayat-ayat Al-Qur`an maupun Sunnah yang melandasi dasar hakhak tersebut. Salah satunya di antaranya: "Dan sungguh, Kami telah memuliakan anak cucu Adam, dan Kami angkut mereka di darat dan di laut dan Kami beri mereka rezeki dari yang baik-baik dan Kami lebihkan mereka di atas banyak makhluk yang Kami ciptakan..."17

Secara garis besar, dilihat dari tingkatannya, setidaknya ada 3 bentuk hak asasi dalam Islam. Pertama, hak dharuriy (hak dasar). Sesuatu dianggap hak dasar apabila hak tersebut dilanggar, bukan hanya membuat manusia sengsara, tetapi juga eksistensinya bahkan hilang harkat kemanusiaannya. Misalnya, bila hak hidup dilanggar maka kehidupan orang itu terancam bahkan mati. Kedua, hak sekunder (bajiy) yakni hak-hak yang bila tidak dipenuhi akan berakibat hilangnya hak-hak mendsar/elementer. Misalnya, hak seseorang untuk mempèroleh sandang pangan yang layak maka akan mengakibatkan hilangnya hak hidup.

${ }^{16}$ Terkait lima hak dasar ini lihat misalnya Abd al-Wahh b Khall f, Tlm Ush l al-Fiqgh (Kairo: Maktabah al-Da'wah al-Isl miyyah Syab b al-Azhar, 1957), hial 197-202 dan Wahbah alZuhail , Usb lal-Fiqb al-Isl m (Damaskus: D I al-Fikr, 1987), hal. 1020-1022.

${ }^{17} \mathrm{QS}$. Al-Isra (17): 70. 
Ketiga hak tersier (tahsiny) yakni hak yang tingkatannya lebih rendah dari hak primer dan sekunder. ${ }^{18}$

Hak hidup dan keselamatan diri merupakan salah satu hak terpokok bagi setiap orang dalam Islam, sehingga melanggar hak tersebut seakan melanggar hak semua orang.Membunuh seorang manusia disamakan dengan membunuh semua manusia, karena membunuh dipandang mengingkari hak hidup. Sejumlah penegasan tersebut tidak sulit ditemukan dalam Al-Qur`an, satu di antaranya:

... dan jangan kamu membunuh jiwa (seseorang), melainkan dengan ada jalan yang dibenatkan", ${ }^{19}$ serta penegasan ayat lain, "... barang siapa membunuh seseorang bukan karena dia (yang membunuh itu telah membunuh orang) maka seolah-olah yang membunuh itu telah membunuh semua manusia, dan barang siapa menghidupkan seseorang, seolah-olah ia telah menghidupkan semua manusia ${ }^{20}$

Untuk menjamin hak hidup pula, Islam mewajibkan masing-masing manusia memelihara hak itu. Di samping penegasan bahwa adanya larangan untuk melibatkan diri pada sesuatu yang membahayakan atau membinasakan dirinya ${ }^{21}$, juga Islam telah menetapkan sejumlah undang-undang atau aturan syara.i. Islam misalnya mewajibkan qisbarh terhadap pembunuhan yang disengaja, juga mewajibkan diyat dan fidyab dalam hal pembunuhan yang tidak disengaja. ${ }^{22}$ Alqur'an mengemukakan tidak kurang dari delapan puiluh ayat tentang hidup, pemeliharaan hidup dan penyediaan sarana hidup.

Al-Qur'an juga berbicara tentang kehormatan dalam sekitar dua puluh ayat. Satu di antaranya, "Barangsiapa yang membunuh seorang manusia, bukan karena orang itu membunuh orang lain, atau bukan karena membuat kerusakan

${ }^{18}$ Lihat Mujamil Qamar, NU Liberal: dari Tradisionalisme Ablussunnab ke Universalisme Islats (Bandung: Mizat, 2002), hal. 204.

${ }^{19}$ QS. Al-An'am (6): 151.

${ }^{20}$ QS. Al-Maidah (5): 32.

${ }^{21}$ Lihat QS. Al-Baqarah (2): 195 yang artinya: "... jangan kamu mencampakean dirimu ke dalam kebinasaan".

${ }^{22}$ Lebih lanjut misalnya dapat dilihat dalam Teungku Muhammad Hasbi Ash Shiddieqy, Islam dan HAM (Doksmen Politik Pokok-Pokok Pikiran Partai Islam dalam Sidang Konstituante 5 Februari 1958),(Jakarta: Pustaka Rizki Putra, 2001). 
di muka bumi, maka seakan-akan ia telah membunuh manusia seluruhnya". ${ }^{23}$ Lebih lanjut Al-Qur'an menjelaskan melalui sekitar seratus lima puluh ayat tentang ciptaan dan makhluk-makhluk, serta tentang persamaan dalam penciptaan. Misalnya: "... Orang yang paling mulia diantara kamu adalah yang paling bertawa diantara kamu." 24

Hak hidup merupakan hak alamiah manusia telah diberikan kepada seluruh ummat manusia sebagai makhluk yang diciptakan dari unsur yang sama dan dari sumber yang sama pula. ${ }^{25}$ Allah menjamin kehidupan, di antatanya dengan melarang pembunuhan dan meng-qishas pembunuh. ${ }^{26}$ Bahkan hak orang sudah meninggal (mayit) sekalipun tetap dijaga. Nabi SAW misalnya menyampaikan: "Apabila seseorang mengkafani mayat saudaranya, hendaklah ia mengkafani dengan baik", atau "Janganlah kamu mencaci-maki orang yang sudah mati, sebab mereka telah melewati apa yang mereka kerjakan. ${ }^{127}$

Dalam Al-Qur'an terdapat sekitar empat puluh ayat yang berbicara mengenai paksaan dan kebencian. Lebih dari sepuluh ayat bicara larangan memaksa, untuk menjamin kebebasan berfikir, berkeyakinan dan mengutarakan aspirasi. Misalnya: "Kebenaran itu datangnya dari Rabb-mu, barangsiapa yang ingin beriman hendaklah ia beriman, dan barangsiapa yang ingin kafir, biarlah ia kafir": ${ }^{28}$ Al-Qur'an juga telah mengetengahkan sekitar tiga ratus dua puluh ayat sikap menentang kedzaliman dan orang-orang yang berbuat dzalim, dan lima puluh empat ayat memerintahkan berbuat adil. Al-Qur`an mengungkapkan adil dengan kata: al-adl, al-qisth, danal-mizan. ${ }^{29}$

Hak-hak lain yang juga dijamin dalam Islam, antara lain tercermin pada hak-hak berikut:

${ }^{23} \mathrm{QS}$. Al-Maidah (5): 32

${ }^{24} \mathrm{QS}$. Al-Hujuraat (49): 13

25Lihat misalnya QS. An-Nisa` (4): 1 dan QS. Ali Imran (3): 195.

${ }^{26}$ Lihat QS. Al-Maidah (5): 32 dan QS. Al-Baqarah (2): 179.

${ }^{27}$ Kedua hadits tersebut diriwayatkan Imam Bukhari.

${ }^{28}$ QS. Al-Kahfi (18): 29

${ }^{29}$ Selengkap lihat Quraish Shihab, Wasvasans Al-Qur'an: Tafsir Maudhuti atas Persoalan Umat, (Bandung: Mizan, 2001), hal. 110-133. 


\section{Hak Kebebasan Beragama dan Kebebasan Pribadi}

Kebebasan pribadi adalah hak paling asasi bagi manusia, dan kebebasan paling suci adalah kebebasan beragama dan menjalankan agamanya, selama tidak mengganggu hak-hak orang lain. Firman Allah: "Dan. seandainya Tuhanmu menghendaki, tentulah beriman orang di muka bumi șeluruhnnya. Apakah kamu memaksa manusia supaya mereka menjadi orang beriman semuanya?"30

Untuk menjamin kebebasan kelompok, masyarakat dan antara negara, Allah memerintahkan memerangi kelompok yang berbuat aniaya terhadap kelompok lain. ${ }^{31}$ Begitu pula hak beribadah kalangan non-muslim. Khalifah Abu Bakar menasehati Yazid ketika akan memimpin pasukan: "Kamu akan menemukan kaum yang mempunyai keyakinan bahwa mereka tenggelam dalam kesendirian beribadah kepada Allah di biara-biara, maka biarkanlah mereka." Khalid bin Walid melakukan kesepakatan dengan penduduk Hirah untuk tidak mengganggu tempat peribadahan (gereja dan sinagog) mereka serta tidak melarang upacara-upacaranya. Kerukunan hidup beragama bagi golongan minoritas diatur oleh prinsip umum ayat "Tidak ada paksaan dalam beragama". ${ }^{32}$

\section{Hak Bekerja}

Islam tidak hanya menempatkan bekerja sebagai hak tetapi juga kewajiban. Bekerja merupakan kehormatan yang perlu dijamin. Nabi saw bersabda: "Tidak ada makanan yang lebih baik yang dimakan seseorang daripada makanan yang dihasilkan dari usaha tangannya sendiri". ${ }^{33}$ Dan Islam juga menjamin hak pekerja, seperti terlihat dalam hadist: "Berilah pekerja itu upahnya sebelum kering keringatnya". ${ }^{34}$

${ }^{30}$ QS. Yunus (10): 99.

${ }^{31}$ QS. Al-Hujurat (49): 9

${ }^{32}$ QS. Al-Baqarah (2): 256.

${ }^{33 H R}$, Bukhariy

${ }^{34} \mathrm{HR}$. Ibn Majah 


\section{Hak Pemilikan}

Islam menjamin hak pemilikan yang sah dan mengharamkan penggunaan cara apapun untuk mendapatkan harta orang lain yang bukan haknya, sebagaimana firman Allah:

Dan janganlah sebagian kamu memakan harta sebagian yang lain diantara kamu dengán jalan bathil dan janganlah kamu bawa urusan harta itu kepada hakim agar kamu dapat memakan sebagian harta benda orang lain itu dengan jalan berbuat dosa padahal kamu mengetahuinya. ${ }^{35}$.

Oleh karena itulah Islam melarang tiba dan setiap upaya yang merugikan hajat manusia. Islam juga melarang penipuan dalam petniagaan. Sabda nabi saw: "Jual beli itu dengan pilihan selama antara penjual dan pernbeli belum berpisah. Jika keduanya jujur dalam jual-beli, maka mereka diberkahi. Tetapi jika berdusta dan menipu berkah jual-bei mereka dihapus". ${ }^{36}$

Islam juga melarang pencabutan hak milik yang didapatkan dari usaha yang halal, kecuali untuk kemashlahatan umum dan mewajibkan pembayaran ganti yang setimpal bagi pemiliknya. Sabda Nabi SAW: "Barangsiapá mengambil hak tanah orang lain secara tidak sah, maka dia dibenamkan ke dalam bumi lapis tujuh pada hari kiamat." Pelanggaran terhadap hak umum lebih besar dan sanksinya akan lebih berat, karena itu berarti pelanggaran tehadap masyarakat secara keseluruhan.

\section{Hak Berkeluarga}

Allah menjadikan perkawinan sebagai sarana mendapatkan ketentraman. Bahkan Allah memerintahkan para wali mengawinkan orang-orang yang bujangan di bawah perwaliannya. ${ }^{37}$ Allah menentukan hak dan kewajiban sesuai dengan fithrah yang telah diberikan pada diri manusia dan sesuai dengan beban yang dipikul individu.

Pada tingkat negara dan keluarga menjadi kepemimpinan pada kepala keluarga yaitu kaum laki-laki. Inilah yang dimaksudkan sebagai kelebihan laki-

${ }^{35}$ QS. Al-Baqarah (2): 188

${ }^{36} \mathrm{HR}$. Khamsah

${ }^{37}$ QS. An-Nuur (24): 32 
laki atas wanita. ${ }^{38}$ Tetapi dalam hak dan kewajiban masing-masing memiliki beban yang sama. "Dan para wanita mempunyai hak yang seimbang dengan kewajibannya menurut cara yang ma'ruf, akan tetapi para suami mempunyai satu tingkatan kelebihan dari istrinya". ${ }^{39}$

\section{Hak Keamanan}

Dalam Islam, keamanan tercermin dalam jaminan keamanan mata pencaharian dan jaminan keamanan jiwa serta harta benda. Firman Allah: "Allah yang telah memberi makanan kepada mereka untuk menghilangkan lapar dan mengamankan mereka dari ketakutan"."

Diantara jenis keamanan adalah dilarangnya memasuki rumah tanpa izin. ${ }^{41}$ Jika warga negara tidak memiliki tempat tinggal, negara berkewajiban menyediakan baginya. Termasuk keamanan dalam Islam adalah memberi tunjangan kepada fakir miskin, anak yatim dan yang membutuhkannya. Olèh karena itulah, Umar bin Khattab menerapkan tunjangan sosial kepada setiap bayi yang lahir dalam Islam baik miskin ataupun kaya. Dia berkata: "Demi Allah yang tidak ada sembahan selain Dia, setiap orang mempunyai hak dalam harta negara ini, aku beri atau tidak aku beri". Umar jugalah yang membawa seorang Yahudi tua miskin ke petugas Baitul-Maal untuk diberikan shadaqah dan dibebaskan dari jizyah.

Bagi para terpidana atau tertuduh mẹmpunyai jaminan keamanan untuk tidak disiksa atau diperlakukan semena-mena. Peringatan rasulullah saw: "Sesungguhnya Allah menyiksa orang-orang yang menyiksa manusia di dunia". ${ }^{2}$ Islam memandang gugur terhadap keputusan yang diambil dari pengakuan kejahatan yang tidak dilakukan. Sabda nabi saw: "Sesungguhnya Allah menghapus dari ummatku kesalahan dan lupa serta perbuatan yang dilakukan paksaan". ${ }^{43}$

\footnotetext{
${ }^{38}$ Q.S An-Nisaa` (4): 34

${ }^{39} \mathrm{QS}$. Al-Baqarah (2): 282

${ }^{40} \mathrm{QS}$. Al-Quraisy 0: $3-4$

${ }^{41}$ QS. An-Nuur (24): 27

${ }^{42} \mathrm{HR}$ Al-Khamsah

${ }^{43} \mathrm{HR}$ Ibn Maajah
} 
Diantara jaminan keamanan adalah hak mendpat suaka politik. Ketika ada warga tertindas yang mencari suaka ke negeri yang masuk wilayah Darul Islam, masyarakat muslim wajib memberi suaka dan jaminan keamanan kepada mereka bila mereka meminta. Firman Allah: "Dan jika seorang dari kaum musyrikin minta perlindungan kepadamu, maka lindungilah ia supaya ia sempat mendengar firman Allah, kemudian antarkanlah ke tempat yang aman baginya". 44

\section{Hak Keadilan dan Persamaan}

Diantara hak setiap orang adalah hak mengikuti aturan syari'ah dan diberi putusan hukum sesuai dengan syari'ah. ${ }^{45}$ Dalam hal ini juga hak setiap orang untuk membela diti dari tindakan tidak adil yang dia terima. Firman Allah swt: "Allah tidak menyukai ucapan yang diucapkan terus-terang kecuali oleh orang yang dianiaya". 46

Merupakan hak setiap orang untuk meminta perlindungan kepada penguasa yang sah yang dapat memberikan perlindungan dan membelanya dari bahaya atau kesewenang-wenangan. Bagi penguasa muslim wajib menegakkan keadilan dan memberikan jaminan keamanan yang cukup. Sabda nabi saw: "Pemimpin itu sebuah tameng, berperang dibaliknya dan berlindung dengannya". ${ }^{47}$

Termasuk hak setiap orang untuk mendapatkan pembelaan dan juga mempunyai kewajiban membela hak orang lain dengan kesadarannya. Rasulullah saw bersabda: "Maukah kamu aku beri tahu saksi yang palng baik? Dialah yang memberi.kesaksian sebelum diminta kesaksiannya". ${ }^{88}$ Tidak dibenarkan mengambil hak orang lain untuk membela dirinya atas nama apapun. Sebab Rasulullah menegaskan: "Sesungguhnya pihak yang benar memiliki pembelaan"49. Seorang muslim juga berhak menolak aturan yang

\footnotetext{
${ }^{44} \mathrm{QS}$. At-Taubah (9): 6

${ }^{45}$ QS. An-Nisaa (4): 79

${ }^{46}$ QS. An-Nisaa' (4): 148

${ }^{47} \mathrm{HR}$. Bukhari dan Muslim

${ }^{48} \mathrm{HR}$ : Muslim, Abu Daud, Nạsai dan Timidzi

${ }^{49} \mathrm{HR}$. Al-Khamsah
} 
bertentangan dengan syari'ah, dan secara kolektif diperintahkan untuk mengambil sikap sebagai solidaritas terhadap sesama muslim yang mempertahankan hak.

Allah mengutus Rasulullah SAW untuk melakukan perubahan sosial dengan mendeklarasikan persamaan dan keadilan bagi seluruh umat manusia. ${ }^{50}$ Manusia seluruhnya sama di mata hukum. Sabda Nabi saw: "Seandainya Fathimah anak Muhammad mencuri, pasti aku potong tangannya". 51

Pada masa Rasulullah banyak kisah tentang kesamaan dan keadilan hukum ini. Misalnya kasus putri bangsawan dari suku Makhzum yang mencuri lalu dimintai keringanan hukum oleh Usamah bin Zaid, sampai kemudian Rasul menegur dengan mengatakan: "...Apabila orang yang berkedudukan di antara kalian melakukan pencurian, dia dibiarkan. Akan tetapi bila orang lemah yang melakukan pencurian, mereka memberlakukan hukum criminal ...". Juga kisah raja Jabalah Al-Ghassani masuk Islam dan melakukan penganiayaan saat haji, Umar tetap memberlakukan hukum meskipun ia seorang raja. Atau kisah Ali yang mengadukan seorang Yahudi mengenai tameng perangnya, dimana Yahudi akhirnya memenangkan perkara.

Umar pernah berpesan kepada Abu Musa Al-Asy'ari ketika mengangkatnya sebagai Qadli: "Perbaikilah manusia di hadapanmu, dalam majlismu, dan dalam pengadilanmu. Sehingga seseorang yang berkedudukan tidak mengharap kedzalimanmu dan seorang yang lemah tidak putus asa atas keadilanmu."

\section{Hak Saling Membela dan Mendukung}

Kesempurnaan iman diantaranya ditunjukkan dengan menyampaikan hak kepada pemiliknya sebaik mungkin, dan saling tolong-menolong dalam membela hak dan mencegah kedzaliman. Bahkan rasul melarang sikap mendiamkan sesama muslim, memutus hubungan relasi dan saling berpaling muka. Sabda nabi saw: "Hak muslim terhadap muslim ada lima: menjawab salam, menjenguk yang sakit, mengantar ke kubur, memenuhi undangan dan mendoakan bila bersin". 52

50Lihat QS. Al-Hadid: 25, Al-A'raf: 157 dan An-Nisa: 5.

${ }^{51} \mathrm{HR}$ Mutafaqun 'Alaihi (Bukhari Muslim).

52HR. Bukhari 
Adanya ajaran tentang HAM dalam Islam menunjukan bahwa Islam sebagai agama telah menempatkan manusia sebagai makhluk terhomat dan mulia. Oleh karena itu, perlindungan dan penghormatan terhadap manusia merupakan tuntutan ajaran itu sendiri yang wajib dilaksanakan oleh umatnya terhadap sesama manusia tanpa terkecuali. Hak-hak yang diberikan Allah itu bersifat permanen, kekal dan abadi, tidak boleh dirubah atau dimodifikasi. ${ }^{53}$ Dalam Islam terdapat dua konsep tentang hak, yakni hak manusia (baq al insan) dan hak Allah. Setiap hak itu saling melandasi satu sama Iain. Hak Allah melandasi manusia dan juga sebaliknya. Dalam aplikasinya, tidak ada satupun hak yang terlepas dari kedua hak tersebut, misalnya sholat. Sementara dalam baq al insan seperti hak kepemilikan, setiap manusia berhak untuk mengelola harta yang dimilikinya.

Selain menekankan pentingnya HAM sebagai limpahan karunia .Allah untuk umat manusia, Islam juga secara simultan melekatkan Kewajiban Asasi Manusia (KAM) dan Tanggung Jawab Asasi Manusia (TAM). Ketiganya menjadi rangkaian tak terpisahkan yang menjadikan perkembangan kajian HAM akan senantiasa relevan dålam tingkat global. ${ }^{54}$ Tujuannya tidak lain agar terjadi keseimbangan antara hak, kewajiban dan tanggung jawab karena dalam kehidupan manusia, ketiganya saling berkaitan. Menuntut hak secara berlebihan tanpa diimbangi kewajiban akan melahirkan masyarakat peminta-minta, sedangkan memenuhi hak tanpa adanya tanggung jawab akan melahirkan masyarakat yang berlebihan, tanpa kontrol.

\section{E. Hak Asasi dalam Memperoleh Pendidikan}

Pendidikanmerupakan usaha sadar dan terencana untuk mewujudkan suasana belajar dan proses pembelajaran agar peserta didik secara aktif mengembangkan potensi dirinya untuk memiliki kekuatan spiritual keagamaan,

\footnotetext{
53Selengkapnya lihat Abu A'la Almaududi (1998), Al-Khilafab wa Al-Mulk, terjemahan: Muhammad Al-Baqir dengan judul Kbilafah dan Kerajaan: Etaluari Kritis Atas Sejarah Penterintahan Islam, Bandung: Mizan.

${ }^{54}$ Syamsuddin Raja, "Wawasan Umat dalam Penegakan Hak Asasi Manusia Perspektif Syari'ah," dalam Iqra: Jamal Ilmu Kependidikart dan Keislaman (Palu: Fakultas Agama Islam Universitas Muhammadiyah Palu, 2008), Vol. 4, No. 2, Hal. 181-197.
} 
pengendalian diti, kepribadian, kecerdasan, akhlak mulia, serta keterampilan, yang diperlukan dirinya, masyarakat, bangsa dan negara. Sementara pembelajaran dipahami sebagai proses interaksi peserta didik dengan pendidik dan sumber belajar pada suatu lingkungan belajar. ${ }^{55}$

Melalui sejumlah Undang-undang yang ada ditegaskan bahwa pendidikan dan pembelajaran merupakan hak bagi setiap warga negara. Penegasan dimaksud antara lain tertuang dalam Undang-undang Sistem Pendidikan Nasional (Sisdiknas) maupun Undang-undang Perlindungan Anak. Salah satu pasal pada Undang-undang Sisdiknas menyebutkan sebagai berikut:

1. Setiap warga negara mempunyai hak yang sama untuk memperoleh pendidikan yang bermutu.

2. Warga negara yang memiliki kelainan fisik, emosional, mental, intelektual, dan/atau sosial berhak memperoleh pendidikan khusus.

3. Warga negara di daerah terpencil atau terbelakang serta masyarakat adat yang terpencil berhak memperoleh pendidikan layanan khusus.

4. Warga negara yang memiliki potensi kecerdasan dan bakat istimewa berhak memperoleh pendidikan khusus.

5. Setiap warga negara berhak mendapat kesempatan meningkatkan pendidikan sepanjang hayat ${ }^{56}$

Sementara Undang-undang Perlindungan Anak menyatakan bahwa setiap anak berhak memperoleh pendidikan dan pengajaran dalam rangka pengembangan pribadinya dan tingkat kecerdasannya sesuai dengan minat dan bakatnya. ${ }^{57}$ Selain itu, Undang-undang Sisdiknas juga menetapkan sejumlah prinsip penyelenggaraan pendidikan agar sejalan dengan prinsip keadilan, menjunjungtinggi nilai-nilai hak asasi manusia setta sejumlah prinsip penting lainnya.Selengkapnya sejumlah prinsip dimaksud antara lain sebagai berikut: pasal 1.

${ }^{55}$ Undang-Undang Nomor 20 tahun 2003 tentang Sistem Pendidikan Nasional (Sisdiknas)

${ }^{56}$ Ibid., pasal 5.

5TUndang-Undang Nomot 23 tahun 2002 tentang Perlindungan Anak pasal 9. 
1. Pendidikan diselenggarakan secara demokratis dan berkeadilan serta tidak diskriminatif dengan menjunjung tinggi hak asasi manusia, nilai keagamaan, nilai kultural, dan kemajemukan bangsa.

2. Pendidikan diselenggarakan sebagai satu kesatuan yang sistemik dengan sistem terbuka dan multimakna.

3. Pendidikan diselenggarakan sebagai suatu proses pembudayaan dan pemberdayaan peserta didik yang berlangsung sepanjang hayat.

4. Pendidikan diselenggarakan dengan memberi keteladanan, membangun kemauan, dan mengembangkan kreativitas peserta didik dalam proses pembelajaran

5. Pendidikan diselenggarakan dengan mengembangkan budaya membaca, menulis, dan berhitung bagi segenap warga masyarakat.

6. Pendidikan diselenggarakan dengan memberdayakan semua komponen masyarakat melalui peran serta dalam penyelenggaraan dan pengendalian mutu layanan pendidikan. ${ }^{58}$

Pada tataran praktis, hubungan antara pendidikan dan hak asasi mesti dipandang sebagai proses yang berhubungan satu sama lain, hal yang satu akan memperkuat hal yang lain. Hal demikian diperlukan untuk dapat menjamin terakomodasinya minat utama dari setiap anak atau peserta didik. Selain itu, keberadaan hak-hak harus tercakup dalam sistem pendidikan nasional maupun internasional.Sekolah-sekolah dan kurikulum harus berorientasi pada upaya penerapan seluruh hak manusia oleh setiap anggota masyarakat.

Pada deklarasi internasional, setidaknya terdapat 5 (ima) perjanjian inti HAM tentang hak atas pendidikan. Kelimanya adalah:

1. Kovenan Internasional tentang Hak-hak Sipil dan Politik(Intemational Covenant on Civil and Political Rights) tahun 1966.

2. Kovenan Internasional tentang Hak-Hak Ekonomi, Sosial dan Budaya (Intemational Covenant on Economic, Social and Cultural Rights) tahun 1966. pasal 4.

${ }^{58}$ Undang-Undang Nomor 20 tahun 2003 tentang Sistem Pendidikan Nasional (Sisdiknas) 
3. Konvensi Internasional tentang Penghapusan Segala Bentuk Diskriminasi Rasial (International Convention on the Elimination of Forms of Racial Discrimination) tahun 1965.

4. Konvensi tentang Penghapusan Segala Bentuk Diskriminasi terhadap Perempuan (Convention on the Elimination of All Forms of Discrimination against (Women) tahun 1979, dan

5. Konvensi tentang Hak-Hak Anak (Convention on the Rights of the Child) tahun 1989.

Selain kelima deklarasi di atas, juga terdapat tiga perjanjian internasional lain yang menjadi tolok ukur dalam upaya global mencapai tujuan Pendidikan Untuk Semua (PUS) dan secara khusus untuk menghapus diskriminasi dalam pendidikan. Ketiganya yaitu: (1) Konvensi UNESCO tentang Penentangan Diskriminasi dalam Pendidikan; (2) Konvensi tentang Penghapusan terhadap Diskriminasi Rasial; dan (3) Konvensi tentang Penghapusan Segala Bentuk Diskriminasi terhadap Perempuan. Fokus tujuan PUS adalah anak-anak sehingga diprioritaskan pada Konvensi tentang Hak-hak memberi petunjuk umumAnak (KHA) terhadap usaha untuk memperbaiki akses pendidikan bagi anak-anak, dan menjelaskan hak-hak anak yang seyogianya diterapkan di bidang pendidikan.

Selain itu, diharapkan terdapat keterkaitan antara pendidikan dan penghapusan kemiskinan, khususnya penghapusan pekerja anak. Pada konteks ini, setidaknya terdapat dua konvensi, yakni: (1) Konvensi tentang Usia Minimumanak untuk Diperbolehkan Bekerja dan (2) Konvensi tentang Penghapusan Bentuk-bentuk Pekerjaan Terburuk Anak.

\section{F. Pendidikan Berbasis FAM}

Melalui integrasi pendidikan dan HAM, semua strategi pendidikan akan saling terkait dengan seluruh HAM dan kebebasan-kebebasan yang bersifat mendasar. $\mathrm{Hal}$ ini misalnya hak untuk bekerja yang betperan penting dalam upaya penuntasan kemiskinan, hak untuk menikah dan membentuk suatu keluarga yang berdampak pada perubahan-perubahan demografi, dan hak untuk 
berpartisipasi dalam politik yang menyorot pentingnya pendidikan untuk membangun seluruh masyarakat.

Pada konteks yang lebih kecil (mikro), hai di atas dapat diwujudkan dalam bentuk pembelajaran berbasis HAM. Pada konteks ini, yang seringkali menjadi sorotán adalah adanya larangan diskriminasi. Bentuk-bentuk diskriminasi selama ini tidak hanya sebatas perbedaan suku, warna kulit, jenis kelamin, agama, atau opini politik saja. Akan tetapi bila merujuk pada Konvensi Hak-Hak Anak, penting diperhatikan penghilangan diskriminasi pada anak-anak yang lahir dari perkawinan yang tidak sah/korban perkosaan, pengidap HIV/AIDS, kelompok minoritas atau memiliki kelainan. Bahkan pada kondisi yang berbeda, masih saja terdapat cara-cara lain yang memungkinkan anak untuk didiskriminasi, misalnya ketika mereka bukan berada dalam kelompok umur yang secara hukum dilindungi; yang usianya terlalu muda kemungkinan akan akan ditolak untuk diterima bersekolah, demikian halnya bagi mereka yang terlalu tua juga akan ditolak.

Bila berpegang pada Konvensi Hak Anak misalnya, maka dituntut untuk mengakui adanya kebutuhan khusus dari anak yang memiliki tingkat kesulitan belajar tertentu. Harus ada langkah untuk mẹjamin anak-anak yang memiliki tingkat kesulitan belajar tertentu memiliki akses yang efektif atas pendidikan. Anak-anak penduduk asli atau minoritas; suku bangsa, agama, bahasa, atau penduduk asli, tidak boleh diabaikan haknya untuk berinteraksi dengan anggota lain dalam kelompoknya, menikmati budayanya, mengakui dan menjalankan agamanya atau menggunakan bahasanya.Pada konteks praktek proses pembelajaran selama ini, hasil belajar yang diharapkan cenderung direfleksikan dalam definisi-definisi berbasiskan mutu. Ditinjau dari perspektif pendidikan berdasarkan hak asasi manusia (HAM), bawaan (intake) dan dampak (impact) petlu dimasukkan ke dalam kerangka kerja standar (masukan-proses-hasil), sehingga kerangka kerjanya menjadi intake-input-process-outcome-impact.

Memang diakui bahwa perjanjian-perjanjian intemasional HAM belum sampai pada pendefinisian pendidikan bermutu, karena hal ini diserahkan kepada setiap negara. Hukum HAM internasional hanya mendefinisikan fungsifungsi yang harus dipenuhi oleh pendidikan (seperti penghapusan terhadap 
diskriminasi, dan tujuan-tujuan yang harus dicapai oleh pendidikan).Pada indikator-indikator yang telah dikembangkan untuk memantau pendidikan dari perspektif HAM dan kemajuan yang dicapai oleh berbagai Negara, nyata berbeda. Terungkap sejumlah perbedaan antar dan dalam Negara. Di satu sisi, di sejumlah sekolah tidak mempunyai perlindungan kesehatan dan keselamatan lingkungan, dan banyak gurunya yang tidak tetlatih dan sering tidak dibayar, sedangkan di sisi lain terdapat banyak sekolah yang berhasil baik dalam tes hasil belajar yang diselenggarakan secara intemasional.

Penilaian atas situasi yang adasekarang dalam konteks pendidikan berbasis HAM di Indonesia, tentu tidak ada sistem pendidikan yang mampu mengembangkan potensi anak sepenuhnya apabila sekolahnya kekurangan peralatan, gedung rusak, tidak aman dan gurunya tidak terlatih. Bahkan penghapusan diskriminasi pun tidak dapat dicapai melalui pendidikan bila anakanak dari kelompok minoritas belajar di sekolah-sekolah betkualitas rendah misalnya. ${ }^{59}$

Hal lain yang menjadi sorotan terkait pendidikan betbasis HAM adalah masih banyak ditemukannya kekerasan terhadap anak (peserta didik) dalam proses pendidikan. Sebagaimana dipahami bahwa yang termasuk kekerasan terhadap anak adalah mencakup semua bentuk perlakuan salah secara fisik dan/atau emosional, penganiayaan seksual, penelantaran, atau eksploitasi secara komersial atau lainnya yang mengakibatkan gangguan nyata ataupun potensial terhadap perkembangan, kesehatan, dan kelangsungan hidup anak ataupun terhadap martabatnya dalam konteks hubungan yang bertanggung jawab, kepercayaan, atau kekuasaan. Masih sering ditemukan sejumlah kekerasan dengan dalih kedisiplinan. Dengan kata hin tidak adanya pembeda antata penerapan kedisiplinan dengan kekerasan.

Proses pembelajaran dengan menerapkan metode-metode mengajar yang menggunakan kekerasan dalam bentuk hukuman fisik atau non-fisik sebagai motivasi, tentu sudah tidak cocok lagi dengan tujuan inti pendidikan. Hal

${ }^{59}$ Sulaiman Zuhdi Manik, "Pembelajaran Berbasis Hak Asasi Manusia", dalam Makalah pada Sosialisasi HAM bagi Tenaga Pendidik di Provinsi Aceh, 9 Februari 2011, Pusat Kajian dan Perlindungan Anak (PKPA) Kementerian Hukum dan HAM RI, Kantor Wilayah Provinsi Aceh. 
tersebut karena sudah terbukti bahwa kekerasan hanya akan melahirkan kekerasan baru atau kekerasan lanjutan.Sebuah studi misalnya mengungkapkan bahwa anak-anak yang dibesarkan di lingkungan keras dan kasar akan membentuk watak indolen, pasif, inferior, tercekam stigma mentalitas rendah diri, pasif, agresif, eksploitatif dan mudah protes atau marah. ${ }^{60}$ Dalam kondisi parah ini, tata nilai yang akan ditanamkari akan sulit, karena rasa percaya diri, pengandalan diri sendiri hampir punah, hingga timbul mental "primitif" dan "sindrom kemiskinan".

Setidaknya terdapat dua hal yang perlu dipertimbangkan keparahan akibatkekerasan yang dialami anak. Dampaknya bukan saja ditentukan tingkat luka tertentu, tapi juga oleh usia anak. Sesuatu yang tidak membahayakan bagi orang dewasa belum tentu tidak membahayakan bagi anak. Demikian pula hubungan si pelaku kekerasan dengan anak. Jika anak dipukul orang yang dicintai, luka batin yang dialaminya jauh lebih menyakitkan dibandingkan jika dilakukan orang tain.

Wujud pelanggaran HAM bagi peserta didik juga seringkali ditemukan pada peserta didik yang mempunyai kebutuhan khusus, seperti peserta didik difabel (cacat) baik fisik maupun mental. Bagi anak berkebutuhan khusus (dengan tingkat kesulitan belajar tertentu), maka perlu ada proses pembelajaran sesuai kebutuhan anak, bukan memaksakan anak menyesuaikan diri terhadap sistem. HAM Internasional mensyaratkan pengakuan anak sebagai individu-individu, tidak terkecuali anak yang berkebutuhan khusus. Nilai dan prinsip. mendasar berupa persamaan (equality), keadilan (justice), kemerdekaan (freedom), martabat manusia (dignity), universalitas (universality), tidak dapat dikecualikan (inalienability), tidak dapat dipisahkan (indivisibility) serta tidak diskriminatif (nondiscriminative) dapat ditegakkan bagi semua peserta didik. Hal ini mutlak diperlukan karena kurangnya akses terhadap pendidikan bermutu akan mempercepat dan menjauhkan peserta didik dari lapangan kerja dan pada akhimya meningkatkan tingkat kemiskinan.

60Lihat misalnya Jumal Perempuan untuk Pencerahan dan Kesetaraan, "Konvensi Hak Anak", diakses dari http://jumalperempuan.com/2011/05/konvensi-hak-anak/ pada 20 Juni 2012 dan Saratri Wilonoyudho, "Nasib Anak Perempuan Jalanan", diakses dari http://www.kesrepro.info/?q=node/135 pada 20 Juni 2012. 
Sekolah dengan sistem pendidikan yang berbasis HAM diharapkan menjelma menjadi sekolah ramah anak (SRA). ${ }^{61}$ Pada SRA, sekolah menjadi tempat yang nyaman dan kondusif bagi anak untuk melangsungkan proses pembelajaran. Sekolah memberikan kesenangan, keleluasaan atau kebebasan kepada anak untuk melakukan pengembangan diri dan berekreasi secara optimal. Hal ini akan melahirkan rasa suka dan termotifasi untuk berkreatifitas sesuai bakat dan minatnya dan akhimya akan dapat membangun kesadaran kritis menuju masyarakat yang kritis dan mandiri.

Di sisi lain, sekolah diharapkan bebas dari segala bentuk tindakkekerasan terhadap anak, baik fisik dannon fisik. Selama ini kekerasan hanya difahami jikadilakukan secara fisik, padahal kekerasan non fisik sangat menyakitkan bagi anak. Sekolah tidak semestinya semena-mena membuat aturan dan kebijakan yang mengekang kebebasan berpikir anak, karena sekolah adalah wadah urituk mencapai harapan dan cita-cita hingga sekolah seharusnya menjadi sahabat yang selalu dicintai dan disenangi.Prinsip-prinsip yang mesti diterapkan pada SRA anțara lain bahwa anak sebagai pusat pembelajaran. Di samping itu, mengutamakan kelangsungan kepentingan hidup dan tumbuh kembang terbaik bagi anak, sehingga anak tidak melakukan diskriminasi terhadap anak dalam bentuk apapun.

\section{G. Penutup}

Pembahasan di atas menunjukkan bahwa pemaknaan akan HAM dapat dilihat dari proses panjang peradaban Barat untuk menemukan keseimbangan antara pemegang kekuasaan dengan rakyat. Ajaran Islam sendiri baik dari Alquian maupun Sunah secara panjang lebar menjelaskan sejumlah hak yang secara prinsip dapat dianggap sebagai HAM, meskipun dalam sejarah, piagam pengakuan HAM secara spesifik tidak ditemukan dalam Islam. Karena itulah dalam konteks Islam, terdapat dialektika pemahaman terhadap HAM beserta implikasinya bagi kebijakan di setiap negara Islam. Kajian ini mengakui adanya perhatian besar dalam ajaran Islam tethadap HAM dan pemenuhannyadalam 
segala bidang menjandi dambaan setiap orang, tidak terkecuali dalam bidang pendidikan.

Dalam konteks Indonesia nampak bahwa upayamemenuhiHAM di bidang pendidikan memerlukan pemahaman dan komitmen bersama dari berbagai pihak terutama pemerintah, mengingat ratifikasi HAM internasional, maupun keberadaan lembaga pendukungnya, tidak serta merta menjadikan HAM di pendidikan dipenuhi secara sempurna, terutama dalam kaitannya dengan- hak anak dalam proses pendidikan.Kajian ini juga mengusulkan pendekatan pendidikan berbasis HAM yang mengerucut pada sekolah yang ramah bagi anak sebagai insan pendidikan utama. Tujuannya agar anak menjadi pusat dalam pemenuhan HAM di bidang pendidikan yang nantinya akan menjadi modal penting bagi pemahaman dan aplikasi HAM pada ranah yang lebih luas.

\section{DAFTAR PUSTAKA}

Al-Maududi, Abu A'la. 1998. Al-Khilafab wa Al-Mulk. Terj: Muhammad AlBaqii, Kbilafab dan Kerajaan: Evaluasi Kritis Atas Sejarah Pemerintaban Islam. Bandung: Mizan.

Ash Shiddieqy, Teungku Muhammad Hasbi. Islam dan HAM (Dokeumen Politik Pokok-Pokok Pikiran Partai Islam dalam Sidang Konstituante 5 Februari 1958). Jakarta: Pustaka Rizki Putra.

Al-Zuhail , Wahbah. 1987. Ush lal-Fiqh al-Islam . Damaskus: Dar al-Fikt.

Effendi, A. Mansyur. 1994. Perkembangan Dimensi Hak Asasi Manusia (HAM) do Proses Dinamika Penyusunan Hukum Hak Asasi Manusia (HAKHAM). Bogor: Ghalia Indonesia.

Emada, Sus Eko. "Issues of Compatibility of Human Rights and Islam: the Experience of Egypt and Indonesia", dalam Joumal of Indonesian Islam. Surabaya: Lembaga Studi Agama dan Sosial, Program Pascasarjana Institut Agama Islam Negeri Sunan Ampel, 2007. Vol. 1, No. 1, Hal. 100-134. 
Fakih, Mansyur, dkk. 2003. Menegakkan Keadilan dan Kemanusiaan. Yogyakarta: Insist Press.

Huda, Qomarul. "Hak-hak Asasi Manusia: Mencari Akar Persamaan antara Islam dengan Barat" dalam Ahkam: Jumal Huksm Islam. Tulungagung. Jurusan Syariah Sekolah Tinggi Agama Islam Negeri Tulungagung, 2009. Vol. 11, No. 1, hal. 36-55.

Hulam, Taufiqul. 2003. "Hụkum Islam Menjunjung Tinggi Hak Asasi-Manusia (HAM): Telaah Kritis atas Kontroversinya dengan Barat dan Aplikasinya dalam Dimensi Etika di Indonesia, dalam Respublica: Jumal Huksm. Riau: Fakultas Hukum Universitas Lancang Kuning, 2003. Vol. 3, No. 1; Hal. 118.

Hudaeri, Mohamad. 2007. "Islam dan Hak Asasi Manusia: Respon Intelektual Muslim"dalam Alqalam: Jumal Ilmiah Bidang Keagamaan dan Kemasyarakatan. Banten: PPPM Institut Agama Islam Negeri Sultan Maulana Hasanuddin, 2007. Vol. 24, No. 3, Hal. 364-386.

Jurnal Perempuan unituk Pencerahan dan Kesetaraan, "Konvensi Hak Anak", diakses dari http://jurnalperempuan,com/2011/05/konvensi-hak-anak/ pada 20 Juni 2012.

Keputusan Presiden Nomor 40 Tahun 2004 tentang Rencana Aksi Nasional Hak Asasi Manusia Indonesia tahun 2004-2009.

Keputusan Presiden Nomor 50 Tahun 1993 tentang Komnas HAM.

Keputusan Presiden Nomor 77 Tahun 2003 tentang Komisi Perlindungan Anak Indonesia (KPAI).

Khallaf, Abd al-Wahhab. 1957. Im Ush l al-Fiqb. Kairo: Maktabah al-Da'wah al-Islamiyyah Syabab al-Azhar.

Manik, Sulaiman Zuhdi. 2011. "Pembelajaran Betbasis Hak Asasi Manusia", dalam Makalah pada Sosialisasi HAM bagi Tenaga Pendidik di Provinsi Aceh, 9 Februari 2011, Pusat Kajian dan Perlindungan Anak (PKPA) Kementerian Hukum dan HAM RI, Kantor Wilayah Provinsi Aceh.

Qamat, Mujamil. 2002. NU Liberal: dari Tradisionalisme Ablussunnab ke Universalisme Islam. Bandung: Mizan. 
Raja, Syamsuddin. 2008. "Wawasan Umat dalam Penegakan Hak Asasi Manusia Perspektif Syari'ah" dalam Iqra: Jumal Imu Kependidikan dan Keislaman. Palu: Fakultas Agama Islam Universitas Muhammadiyah. Palu, 2008. Vol. 4, No. 2, hal, 181-197.

Shihab, Quraish. 2001. Wawasan Al-Qur'an: Tafsir Maudbu'i atas Persoalan Umat. Bandung: Mizan.

Surat Keputusan Komisi Perlindungan Anak Indonesia Nomor 02/KPAI/IX/2004 tentang Pedoman Pembentukan Komisi Perlindungan Anak Indonesia Daerah (KPAID).

Tap MPR RI Nomor XVI//MPR/1998 tentang Hak Asasi Manusia.

Undang-Undang Dasar Negara Republik Indonesia Tahun 1945.

Undang-Undang Nomor 20 tahun 2003 tentang Sistem Pendidikan Nasional (Sisdiknas).

Undang-Undang Nomor 23 tahun 2002 tentang Perlindungan Anak. Undang-Undang Nomor 26 tahun 2000 tentang Pengadilan HAM. Undang-Undang Nomor 39 Tahun 1999 tentang Hak Asasi Manusia (HAM). Wilonoyudho, Saratri. "Nasib Anak Perempuan Jalanan", diakses dari http://www.kestepro.info/?q=node/135 pada 20 Juni 2012. 